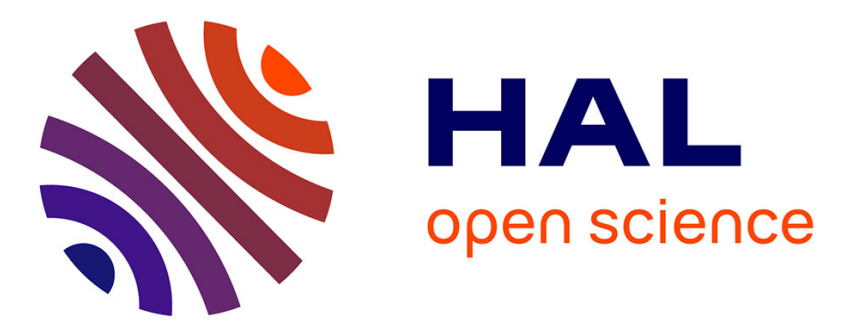

\title{
Analytical Study of Bending Behavior for Concrete Beams with T-Shaped Cross Section using Composite and Steel Bars
}

Seyedeh Zahra Hosseini Ghaziyani, Seyedamin Mostafavian, Meysam Azizpour Chirani

\section{To cite this version:}

Seyedeh Zahra Hosseini Ghaziyani, Seyedamin Mostafavian, Meysam Azizpour Chirani. Analytical Study of Bending Behavior for Concrete Beams with T-Shaped Cross Section using Composite and Steel Bars. American Journal of Engineering and Applied Sciences, 2018, 11 (2), pp.979-985. 10.3844/ajeassp.2018.979.985 . hal-01839647v2

\section{HAL Id: hal-01839647 \\ https://hal.science/hal-01839647v2}

Submitted on 23 Oct 2020

HAL is a multi-disciplinary open access archive for the deposit and dissemination of scientific research documents, whether they are published or not. The documents may come from teaching and research institutions in France or abroad, or from public or private research centers.
L'archive ouverte pluridisciplinaire HAL, est destinée au dépôt et à la diffusion de documents scientifiques de niveau recherche, publiés ou non, émanant des établissements d'enseignement et de recherche français ou étrangers, des laboratoires publics ou privés. 
Original Research Paper

\title{
Analytical Study of Bending Behavior for Concrete Beams with T-Shaped Cross Section using Composite and Steel Bars
}

\author{
${ }^{1}$ Seyedeh Zahra Hosseini Ghaziyani, ${ }^{2}$ Seyedamin Mostafavian and ${ }^{3}$ Meysam Azizpour Chirani \\ ${ }^{1}$ MSc of Civil Engineering, Rasht, Iran \\ ${ }^{2}$ Department of Civil Engineering, Payame Noor University (PNU), Tehran, Iran \\ ${ }^{3} \mathrm{MSc}$ of Civil Engineering, Rasht, Iran
}

\author{
Article history \\ Received: 31-03-2018 \\ Revised: 03-05-2018 \\ Accepted: 14-05-2018 \\ Corresponding Author: \\ Seyedeh Zahra Hosseini \\ Ghaziyani \\ MSc of Civil Engineering, \\ Rasht, Iran \\ Email: hosseini.saze@gmail.com
}

\begin{abstract}
Todays, instead of steel reinforcements, Fiber Reinforced Polymer (FRP) rebars have been using in the reinforced concrete structures. By consideration of different strain-stress behavior between steel and composite material, it is necessary to evaluate the difference of these two materials inside of RC beams. In this research, twelve reinforced concrete T-shape beams were modeled using ABAQUS finite element software. Six of the beams performed as T-shape in which three of them reinforced with FRP rebars and three others were reinforced with steel rebars. As the same as first six beams property, other six beams defined by rectangular performance. The nonlinear static method was used to analysis and load-displacement diagram had been taken to compare the results. The results showed that, the stiffness of T-shape beam is much more than the beams with rectangular performance. Moreover, by comparing FRP and steel rebars, using the FRP rebars reduced stiffness and increased the load capacity.
\end{abstract}

Keywords: FRP Reinforcement, T-Shape Concrete Section, Finite Element Method, Nonlinear Analysis

\section{Introduction}

Generally, strengthening by Fiber Reinforced Polymer (FRP) has been using in order to increase to load capacity and ductility of reinforced concrete structures. In this case, there are two common FRP material include FRP sheets and FRP reinforcements. The FRP rebars has better performance compared with steel rebars like lower density, high strength and etc. So, they are one of the best method to be replaced by regular steel rebars (Mosallam et al., 2003; Mirmiran et al., 2001). Saadatmanesh and Ehsani (1998) had studied on the RC beams with were reinforced by Glass Fiber Reinforced Polymer (GFRP). In his evaluation, the longitudinal and transvers rebars were used. The results indicated that, the maximum expected theoretical and calculated force was better in beams reinforced by GFRP bars. The longitudinal cracks were normally distributed and the width of tensile crack for beams with GFRP bars was a little bit bigger than beams with steel bars. This was occurred on the grounds of the lower tensile module of elasticity. Dias and Barros (2017) had investigation on shear strengthening of T-cross section RC beam using Near Surface Mounted (NSM) with CFRP laminate. In his experimental research, the result indicated that using this method increased the load capacity and the tensile behavior of beam. Moreover, by increasing the height of the T-shape beam, the effect of CFRP increases. Naseri et al. (2009) evaluated the shear and flexural criteria of RC beams retrofitted by GFRP sheets. Their results showed that the ductility of beams retrofitted in shear and flexural area reduced and deflection of retrofitted beams compared with beams without retrofitting was similar. Andrew et al. (2017) did analytical study on T-shape reinforced concrete beam which he evaluated the behavior of the beam by different equations base on wave propagation coefficients. Nie et al. (2018) had experimental study on RC T-Section beam with FRP web strength opening. His results showed that, the size of web opening can be effective in flexural capacity so that increasing the size of opening decrease the flexural capacity.

Fallahi et al. (2018) had numerical study on RC frame with infilled wall under cyclic loading. In their research, they used the CFRP sheets to retrofit the whole system with different retrofitting shapes. The outcomes declared that using CFRP can increase the load capacity of RC frames. Soleimani et al. (2015) and Roudsari et al. (2018) had numerical investigation of RC beams under extreme 
Seyedeh Zahra Hosseini Ghaziyani et al. / American Journal of Engineering and Applied Sciences 2018, 11 (2): 979.985 DOI: 10.3844/ajeassp.2018.979.985

loading as an impact loading with ABAQUS using Dynamic Explicit Analysis. In this study, he evaluated the effect of retrofitting by GFRP sheets and CFRP and GFRP rebars compared to just steel rebars. The results showed, FRP rebars had much more better performance in increasing load capacity and ductility. Also, retrofitting by GFRP sheets could increase the load capacity compared with steel reinforced concrete beam. Tang et al (2006) studied on the flexural behavior of $\mathrm{RC}$ beams retrofitted by FRP bars using NSMR method. This result showed that using GFRP bars could increase stiffness and bening loading capacity and reduced ultimate deflection. Gregoria et al. (2018) used the failure criteria to predict the shear capacity of reinforced concrete beam. His theoretical studies declare that using the method of predication provided a closer fit to experimental variables. Nayak et al. (2018) had experimental test on RC beam externally retrofitted by GFRP. He tested one control beam and nine retrofitted beam which the results showed that the wrapping up the tensile faces of beam had super performance in increasing flexural capacity.

\section{Finite Element Models}

In this research the behavior of two different groups of $\mathrm{RC}$ beams have been investigated. The first group includes GFRP bars and the second group contains steel bars which in each group the beams have been designed as rectangular and $\mathrm{T}$-shape performance. In order to evaluate the RC beams, ABAQUS software is used.

\section{Geometry and Mechanical Properties}

In the term of geometry, the total length of the beams is considered 4 meters with simple support at both ends. Moreover, the T-shape beam has $420 \mathrm{~mm}$ height, 300 $\mathrm{mm}$ width of flange, $180 \mathrm{~mm}$ web width and the thickness of flange is $90 \mathrm{~mm}$. Table 1 . showed the geometry parameters of beam which used low steel (called D), intermediate steel (called B) and finally high steel rate (called $\mathrm{U}$ ). It should be noted that the details of this design based on reference (Hosseini, 2016).

In addition, the details of rectangular-shape beam shown in Table 2 in which the height of the beam is $270 \mathrm{~mm}$, the flange thickness is $375 \mathrm{~mm}$, the web thickness is 180 and flange thickness is assigned 110 $\mathrm{mm}$. It also has low, intermediate and high steel rate based of same design. (Hosseini, 2016).

The mechanical properties of beam can be seen in Table 3. In this research, the longitudinal and transvers bars are in the type of AIII and AII, respectively. The diameter of bar is $10 \mathrm{~mm}$, module of elasticity (E) $2.05 \times 10^{5}$ and poison ratio is 0.3 . Moreover, the plastic criteria of the longitudinal and transvers bars are shown in Table 3 and 4. And the mechanical properties of GFRP bars is in the Table 5. The module of elasticity, poison ratio and density are $21 \mathrm{~N} / \mathrm{mm}^{2}, 0.2$ and $240 \mathrm{Kgf} / \mathrm{m}^{3}$. Table 6 is shown the plastic parameter of concrete.

Table 1: The details of reinforcement in T-shape Beam

\begin{tabular}{lllll}
\hline & & Model & & \\
No & Model & Specification & Diameter $(\mathrm{mm})$ & Stretch Rebar \\
\hline 1 & $\mathrm{~S}_{1}$ & DS32 & 32 & 2STEELØ32 \\
2 & $\mathrm{~S}_{2}$ & BS34 & 34 & 2STEELØ34 \\
3 & $\mathrm{~S}_{3}$ & US36 & 36 & 2STEELØ36 \\
4 & $\mathrm{G}_{1}$ & DG32 & 32 & 2GFRPØ32 \\
5 & $\mathrm{G}_{2}$ & BG34 & 34 & 2GFRPØ34 \\
6 & $\mathrm{G}_{3}$ & UG36 & 36 & 2GFRPØ36 \\
\hline
\end{tabular}

Table 2: The details of reinforcement in Rectangular-shape Beam

\begin{tabular}{lllll}
\hline No & Model & $\begin{array}{l}\text { Model } \\
\text { Specifications }\end{array}$ & $\begin{array}{c}\text { Diameter } \\
(\mathrm{mm})\end{array}$ & Stretch Rebar \\
\hline 7 & $\mathrm{~S}_{4}$ & DS 32 & 32 & 2STEEL Ø32 \\
8 & $\mathrm{~S}_{5}$ & BS34 & 34 & 2STEEL Ø34 \\
9 & $\mathrm{~S}_{6}$ & US36 & 36 & 2STEEL Ø36 \\
10 & $\mathrm{G}_{4}$ & DG32 & 32 & 2GFRPØ32 \\
11 & $\mathrm{G}_{5}$ & DG34 & 34 & 2GFRPØ34 \\
12 & $\mathrm{G}_{6}$ & DG36 & 36 & 36 Ø 2GFRP \\
\hline
\end{tabular}

Table 3: Plastic parameter of longitudinal bars

\begin{tabular}{ll}
\hline Yield stress $(\mathrm{MPa})$ & Plastic strain \\
\hline 400 & 0 \\
600 & 0.1 \\
\hline
\end{tabular}

Table 4: Plastic parameter of transvers bars

\begin{tabular}{ll}
\hline Yield stress $(\mathrm{MPa})$ & Plastic strain \\
\hline 300 & 0 \\
500 & 0.1 \\
\hline
\end{tabular}

Table 5: Mechanical parameter of GFRP bars

\begin{tabular}{llll}
\hline $\begin{array}{l}\text { Diameter } \\
\text { and Nagpal) }\end{array}$ & $\begin{array}{l}\text { Tensile } \\
\text { strength (MPa) }\end{array}$ & $\begin{array}{l}\text { Tensile modulus } \\
\text { of elasticity (Carey, Werfel }\end{array}$ & $\begin{array}{c}\text { Ultimate } \\
32\end{array}$ \\
32 & 551 & 46 & $1.19 \%$ \\
36 & 482 & 46 & $1.04 \%$ \\
36 & 448 & 46 & $0.97 \%$ \\
\hline
\end{tabular}

Table 6: Plastic parameter of concrete

\begin{tabular}{lllll}
\hline Dilation Angle & Eccentricity & $\mathrm{fb} 0 / \mathrm{fc} 0$ & $\mathrm{~K}$ & $\begin{array}{l}\text { Viscosity } \\
\text { parameter }\end{array}$ \\
\hline 20 & 0.1 & 1.16 & 0 & 0 \\
\hline
\end{tabular}

\section{Modeling in ABAQUS}

By considering 3D modeling in this research, the concrete damage plasticity model is used to define the concrete behavior. In this case, the parametrical study by Roudsari et al., (2017: 2018) has been used. He did numerical study using MATLAB toolbox in order to find out the compressive and tensile parameters of concrete and the corresponding damages. In his research, he used this model to validate the RC column with experimental test. The result showed very good accuracy in the maximum outcomes and its trends. Moreover, the beam is defined as solid part with C3D8R meshing family which $\mathrm{R}$ indicates the reduce integration method of analyzing. The Fig. 1 showed the type of element. Also, in order to model of longitudinal and transvers bars, the truss element is used because of the capability of having axial load. 
Seyedeh Zahra Hosseini Ghaziyani et al. / American Journal of Engineering and Applied Sciences 2018, 11 (2): 979.985 DOI: 10.3844/ajeassp.2018.979.985

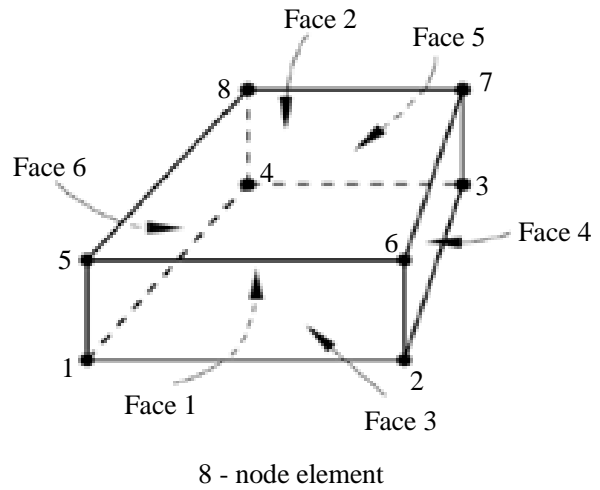

Fig. 1: Element family: C3D8R and the node number coordinate
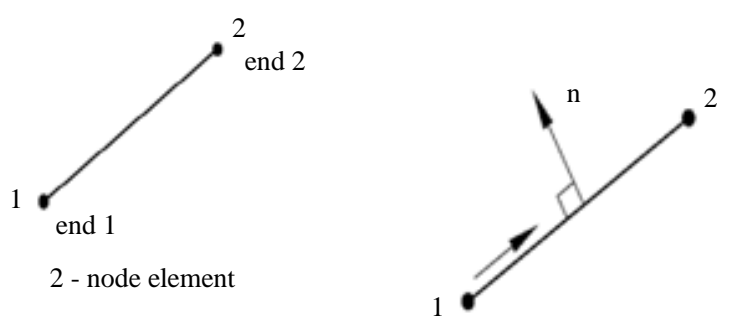

Fig. 2: Truss element and the normal vector

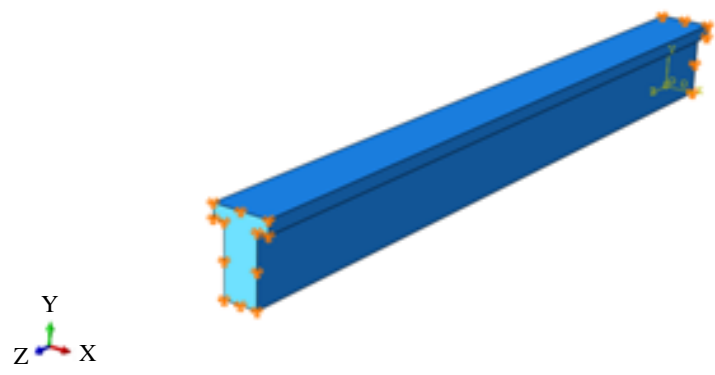

Fig. 3: Loading condition of T-shape beam

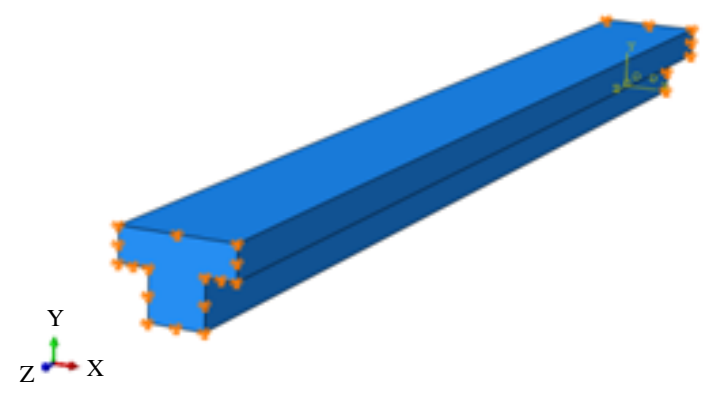

Fig. 4: Loading condition of rectangular-shape beam

Figure 2 indicates the truss element behavior. It should be noted that, Nonlinear static general analysis is used into this research and the boundary condition of both end of the beam is considered as simple support $(\mathrm{U} 1=\mathrm{U} 2=\mathrm{U} 3=0)$ and the load applied as pressure.

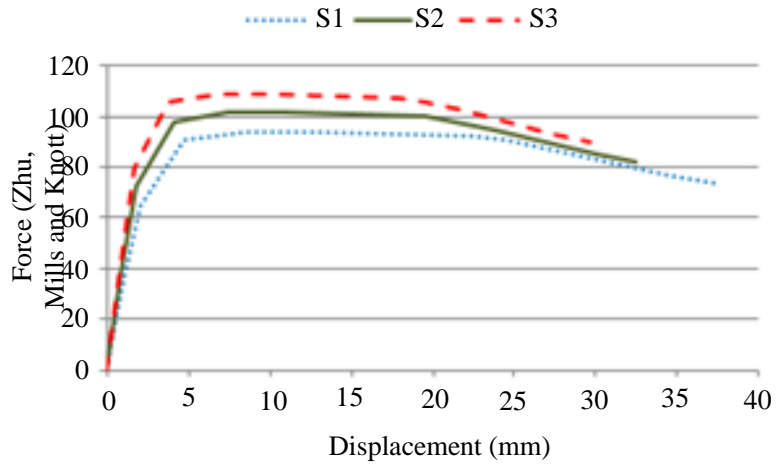

Fig. 5: Loading-displacement of T-shape beam using steel bar

Finally, the displacement is taken from the middle span on the bottom surface of them beam. Figure 3 and 4 are shown the boundary condition of T-shape and Rectangular-shape of the beam, respectively.

\section{T-Shape Result}

In the Fig. 5 the result of T-shape beam models as the load-displacement diagram is shown by comparing the S1 (low steel), S2 (intermediate steel) and S3 (high steel). As it is clear, the more bar diameter caused more load capacity in which S3 with 2 longitudinal $36 \mathrm{~mm}$ bars had the most load capacity as $108.83 \mathrm{KN}$. In addition, $\mathrm{S} 1$ model by having the low steel rate has the maximum ductility. And the stiffness of S3 is more than two other models. In Fig. 6. is shown the loaddisplacement diagram of beams with FRP bars. It can be seen that by increasing the cross-section area of GFRP, T-shape beam had more load capacity. G3 model with two $36 \mathrm{~mm}$ diameter of GFRP bars had the maximum load capacity in comparison of two other models. The deflection of G1 also with $32 \mathrm{~mm}$ diameter GFRP bars was a little bit more than two other beams in this groups.

\section{Rectangular-Shape Result}

The load-displacement diagram of rectangular-shape beam models is shown in Fig. 7. In this figure, the maximum load capacity of model S6 is more than other beams in this group and model of $\mathrm{S} 4$ has the maximum deflection and S6 also has the maximum stiffness. Moreover, in the Fig. 8. The load capacity of rectangularshape beam with GFRP bars has been shown. The model of G6 with the maximum cross-section area of GFRP compared to G5 and G4 in which this model (G6) has the maximum load capacity, too. The deflection of G4 with two GFRP bars ( $32 \mathrm{~mm}$ diameter) is smaller than other two models. Eventually, the stiffness of G6 is more than G5 and G4.

The contours of stress distribution for model S2 (Tshape with steel bars) is shown in Fig. 9. Which the maximum compressive stress is $30.8 \mathrm{MPa}$ so that it was more that the compressive strength of concrete. By considering this issue, it can be declared that the support area has some cracks. Furthermore, Fig. 10. 
Seyedeh Zahra Hosseini Ghaziyani et al. / American Journal of Engineering and Applied Sciences 2018, 11 (2): 979.985 DOI: 10.3844/ajeassp.2018.979.985

The middle span of the beam has cracks, too. The reason of cracking can be on the wake of the ultimate tensile stress as $3.05 \mathrm{MPa}$ which is more than allowable tensile stress. In model of $\mathrm{G} 2$, the beam with T-shape performance and GFRP bars had 36.72 compressive stress (Fig. 11). Also, by looking at the Fig. 12. It can be seen that the maximum strain of the concrete is 0.0098 which is much more than the normal concrete strain (0.003).

In the Fig. 13 and 14 the comparisons between beam with steel and GFRP bars is shown. As it is assent, using FRP bars can increase the load capacity. Also, the stiffness of models with GFRP bars are more than others.

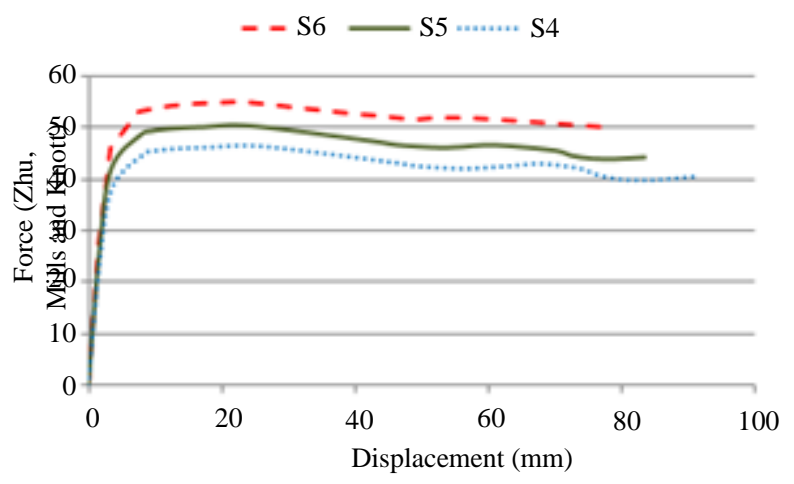

Fig. 7: Loading-displacement of rectangular-shape beam using steel bar

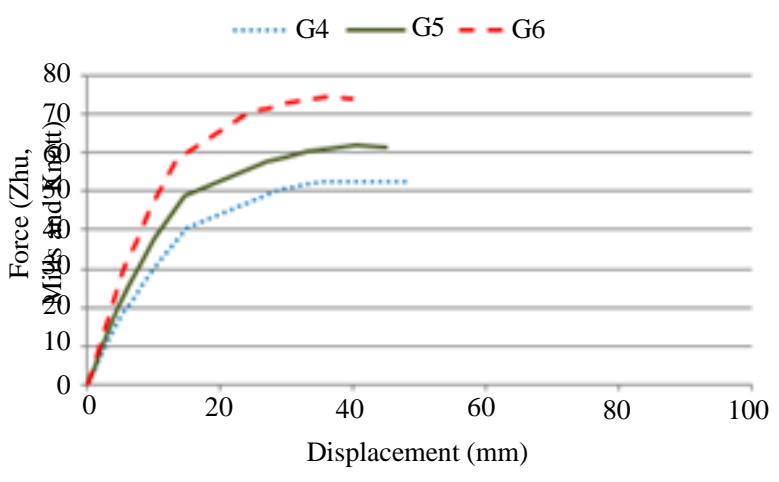

Fig. 8: Loading-displacement of rectangular-shape beam using GFRP bar

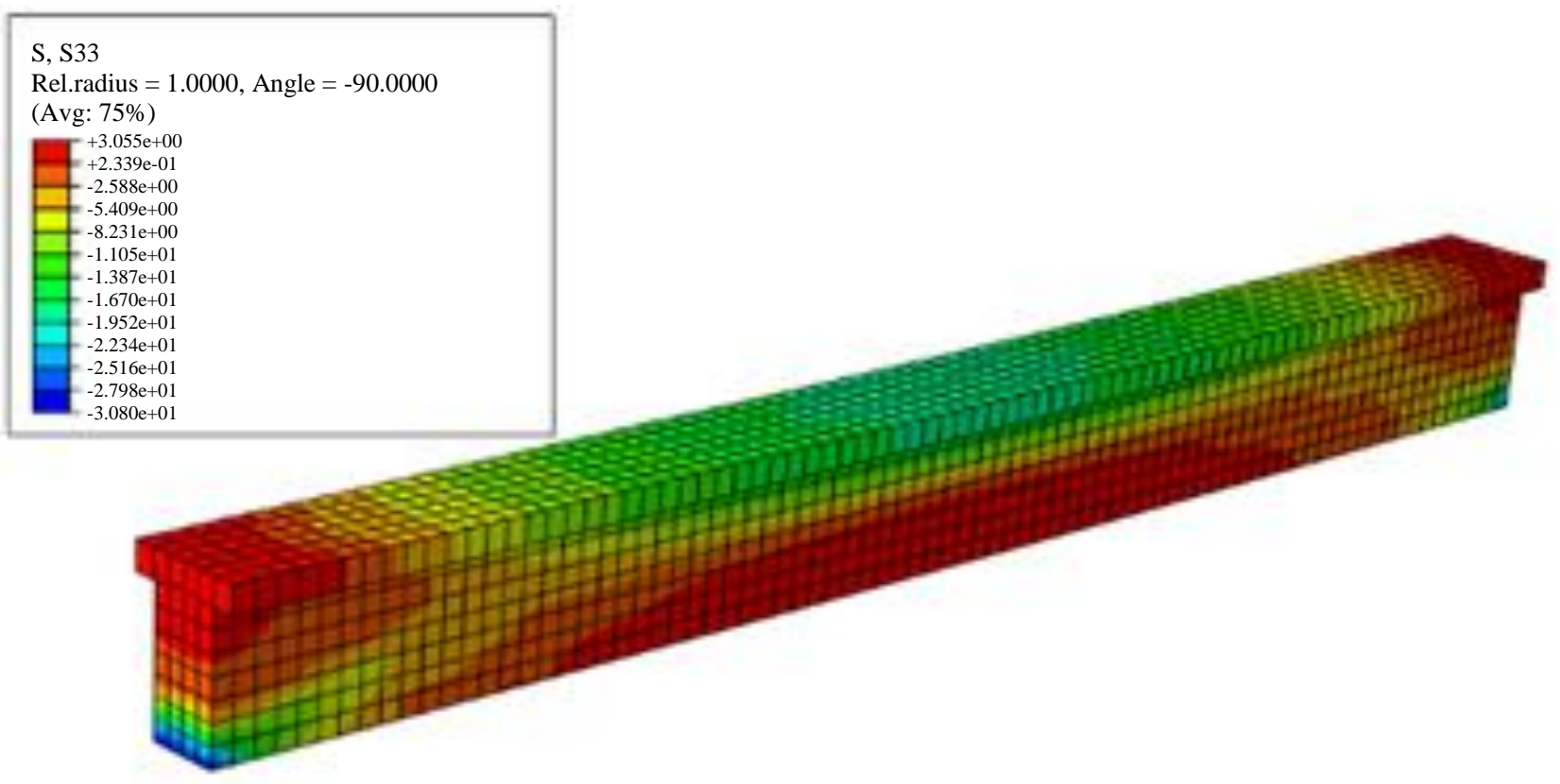

Fig. 9: Stress distribution of S2 
Seyedeh Zahra Hosseini Ghaziyani et al. / American Journal of Engineering and Applied Sciences 2018, 11 (2): 979.985 DOI: 10.3844/ajeassp.2018.979.985

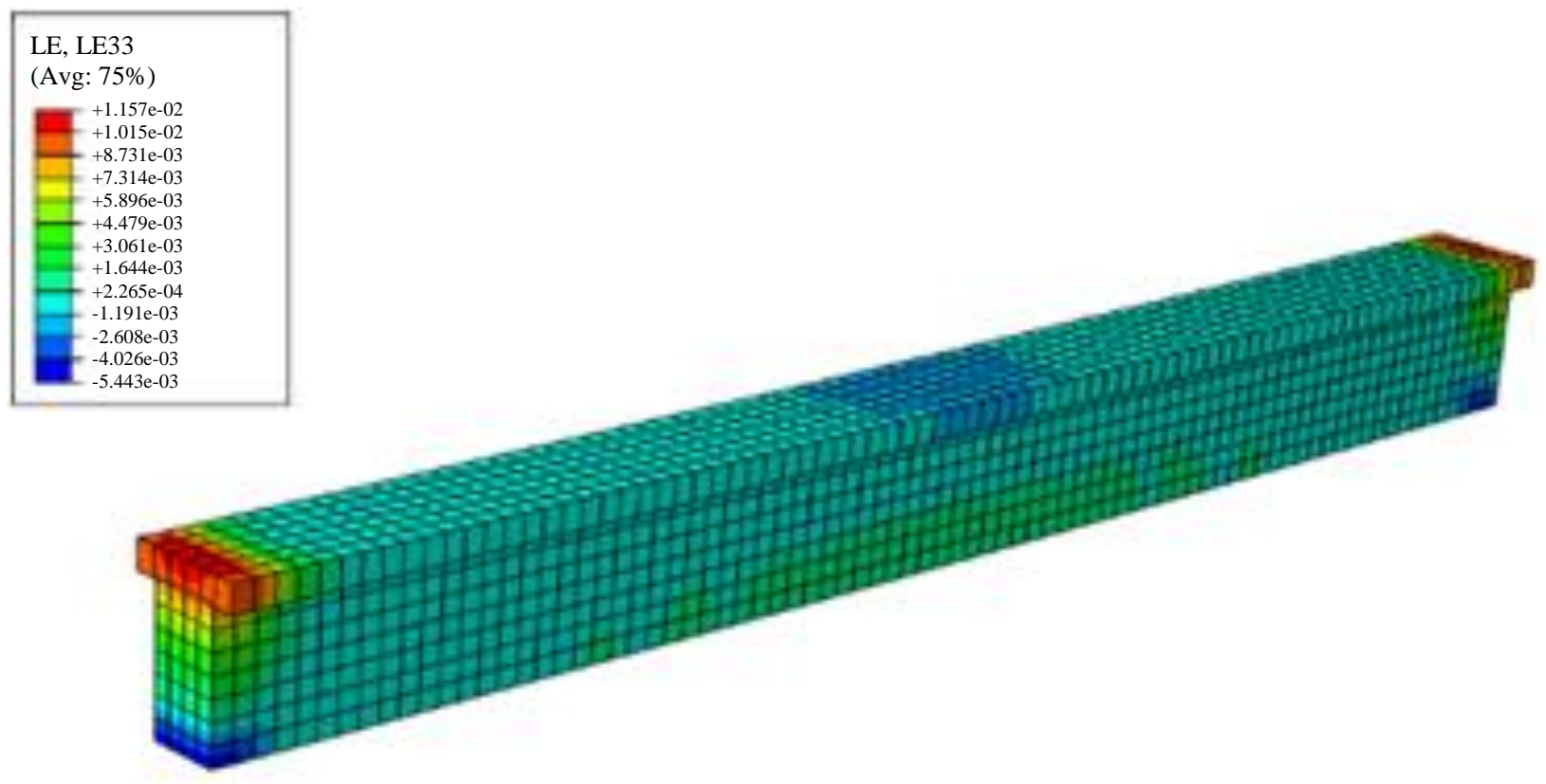

Fig. 10: Strain distribution of $S 2$

S, S33

Rel .radius $=1.0000$, Angle $=-90.000$

(Avg: $75 \%)$

$+3.118 \mathrm{e}+00$

$-2.019 \mathrm{e}-01$

$-3.522 \mathrm{e}+00$

$-6.841 \mathrm{e}+00$

$-1.016 \mathrm{e}+01$

$-1.348 \mathrm{e}+01$

$-1.680 \mathrm{e}+01$

$-2.012 \mathrm{e}+01$

$-2.344 \mathrm{e}+01$

$-2.676 \mathrm{e}+01$

$-3.008 \mathrm{e}+01$

$-3.340 \mathrm{e}+01$

$-3.672 \mathrm{e}+01$

Angle $=-90.000$

Fig. 11: Stress distribution of G2

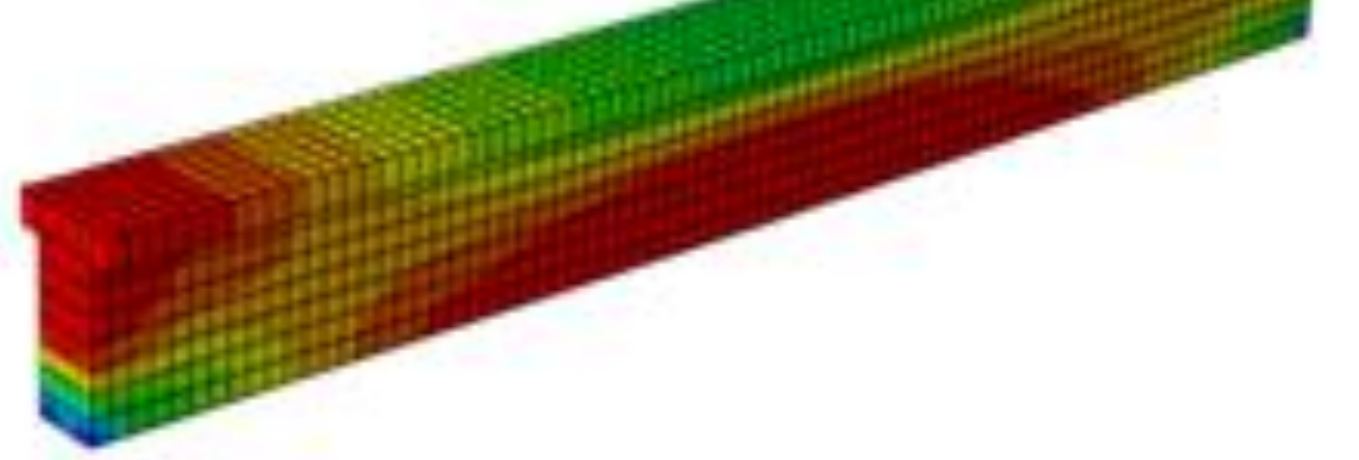


Seyedeh Zahra Hosseini Ghaziyani et al. / American Journal of Engineering and Applied Sciences 2018, 11 (2): 979.985 DOI: 10.3844/ajeassp.2018.979.985

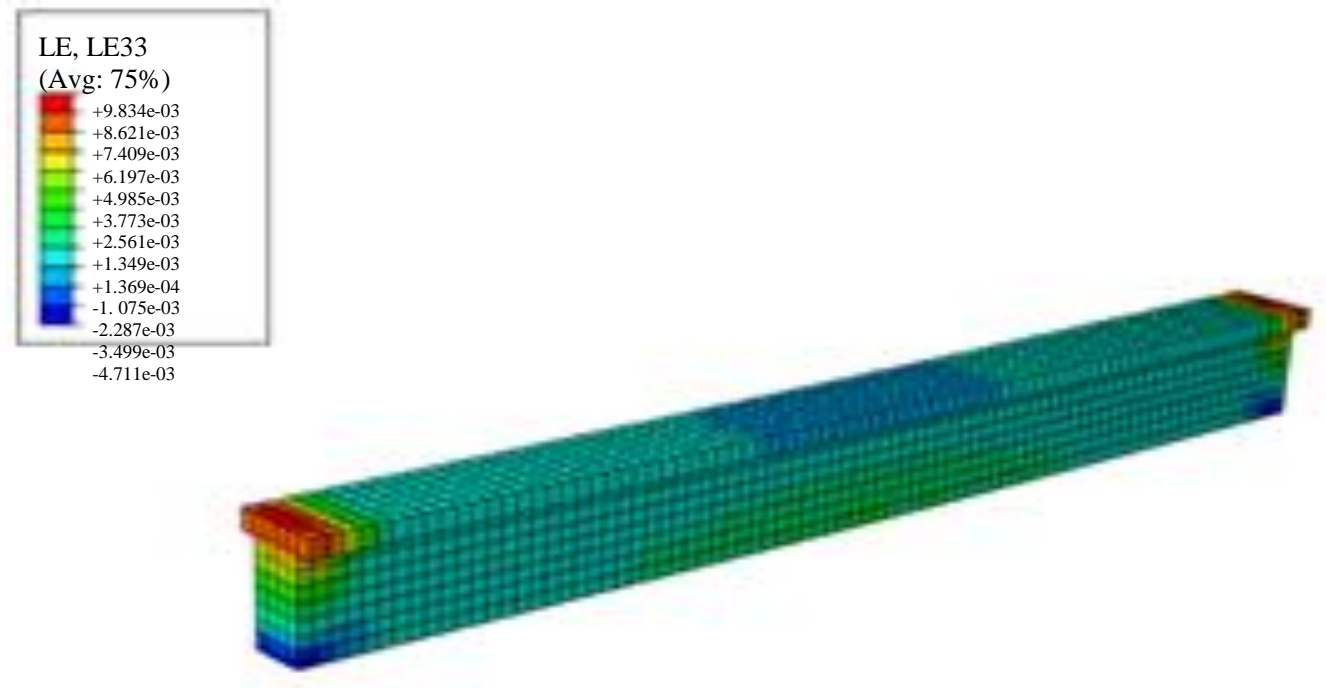

Fig. 12: Strain distribution of G2

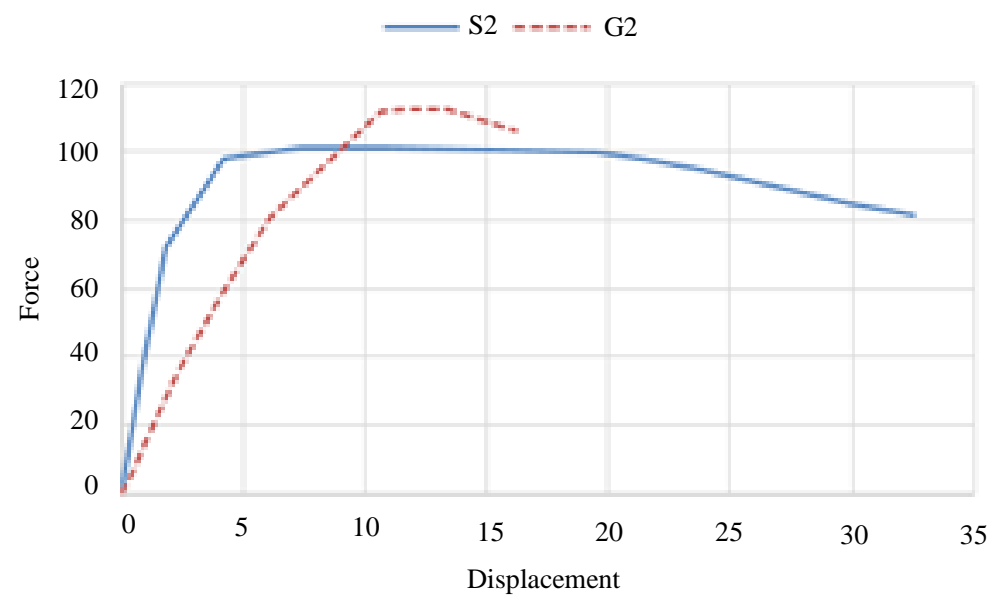

Fig. 13: Load-displacement diagram comparisons for $\mathrm{S} 2$ and G2

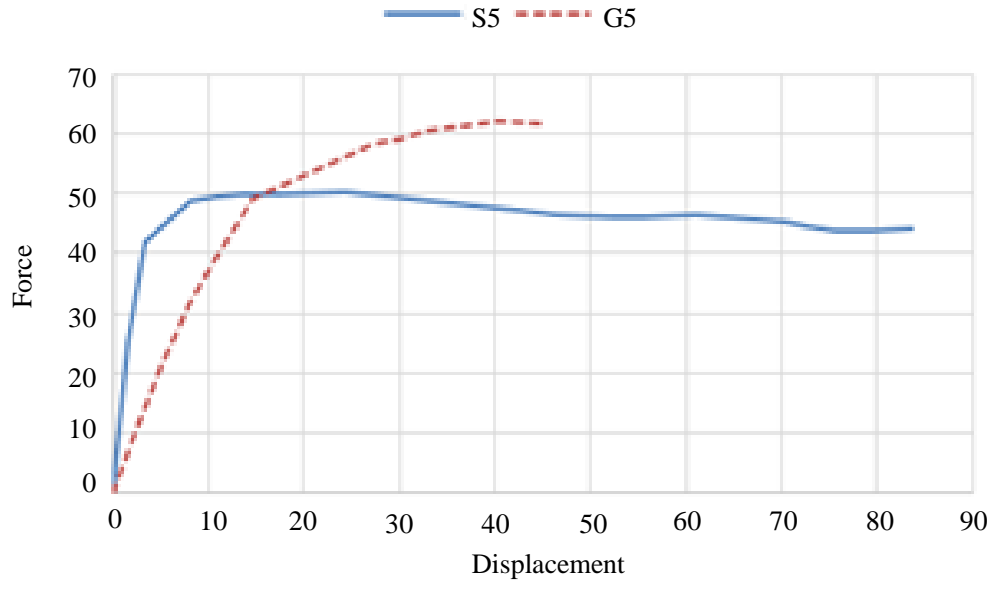

Fig. 14: Load-displacement diagram comparisons for S5 and G5

Conclusion 
Seyedeh Zahra Hosseini Ghaziyani et al. / American Journal of Engineering and Applied Sciences 2018, 11 (2): 979.985 DOI: 10.3844/ajeassp.2018.979.985

In this research, the flexural behavior of RC beams using steel and GFRP bars has been assessed:

- Using GFRP bars can increase load capacity from $11.19 \%$ to $48.15 \%$

- GFRP bars improve the stiffness of RC beam

- Beams with steel bars have better ductility compared with GFRP

- T-shape beam has better performance in comparison with rectangular-shape beam

\section{Author's Contributions}

Seyedeh Zahra Hosseini Ghaziyani: Provided the research topic and guided the research development and modeling. Also, participated in writing the manuscript.

Seyedamin Mostafavian: Provided the research topic and guided the research development and data analysis and modeling. Also, participated in writing the manuscript.

Meysam Azizpour Chirani: Designed the research plan and organized the study. Also, participated in writing the manuscript.

\section{Ethics}

This article is an original research paper. There are no ethical issues that may arise after the publication of this manuscript.

\section{References}

Waiching Tang, R.V. Balendran, Abid Nadeem, H.Y. Leung, 2006. Flexural strengthening of reinforced lightweight polystyrene aggregate concrete beams with near-surface mounted GFRP bars. Building and Environment.41(ASTM C1017):13811393.DOI:10.1016/j. buildenv.2005.05.029

Andrew, J., D.P. Hull and L. Cox, 2017. An analytical model of a curved beam with a $\mathrm{T}$ shaped cross section. J. Sound Vibrat., 416: 29-54.

Dias, S.J.E. and J.A.O. Barros, 2017. NSM shear strengthening technique with CFRP laminates applied in high $\mathrm{T}$ cross section $\mathrm{RC}$ beams. Composites Part B: Eng., 114: 256-267. DOI: 1016/j.compositesb.2017.01.028

Fallahi, M., S.S. Roudsari, M. Haghighfar, R. Madandoust and, 2018. Modeling of reinforced concrete frames with Infill walls under cyclic loading Strengthening with CFRP, Am. J. Eng. applied Sci. DOI:10.3844/ajeassp.2018

Gregoria, M. D.M. Kotsovou and M. Cotsovos, 2018. Shear failure criterion for RC T-beams.
Hosseini, G.Z., 2016. Investigation of difference in flexural behavior of the winged concrete section reinforced with FRP bars and steel bars by finite element method. Saroyeh Higher Education Institute.

Mirmiran, A., Y. Wnqing and C. Xiabing, 2001. Design for slenderness in concrete columns internally reinforced with fiber reinforced polymer bars. ACI Structural J., 98: 116-125. https://www.researchgate.net/publication/28834405 9_Design_for_Slenderness_in_Concrete_Columns_I nternally_Reinforced_with_FRP_Bars

Mosallam, A., M. Haroun, M. Mossaad and S. Zakaria, 2003. Polymer composites repair and rehabilitation materials for the new era. New Era Build.

Naseri, H., M. Miri, H. Beheshtinezhad and A. Arjmandfar, 2009. Investigation of flexural and shear behavior of $\mathrm{T}$-shape beams reinforced with Gfrp fibers. Eiqhth Int. Civil Eng. Congress.

Nayak, A.N., A. Kumari and R.B. Swain, 2018. Strengthening of rc beams using externally bonded fiber reinforced polymer composites. 14: 137-152.

Nie, X.F., S.S. Zhang, B.J.G. Tenga and G.M. Chenc, 2018. Experimental study on RC T-section beams with an FRP-strengthened web opening.

Roudsari, S.S., S.A. Hamoush, S.M. Soleimani, T.A. Lebdeh and M. Haghighfar, 2018. Analytical study of reinforced concrete beams strengthened by frp bars subjected to impact loading condition. Am. J. Eng. applied Sci. DOI: 10.3844/ofsp.11916

Roudsari, Sajjad Sayyar;, et al. "Evaluation of LargeSize Reinforced Concrete Columns Strengthened for Axial Load Using Fiber Reinforced Polymers." Engineering Structures 178 (2019): 680-93. Print.

Soleimai .M.S. and Roudsari.S.S, 2015. Analytical study of reinforced concrete beams tested under impact loading. Proceedings of the 4th International Workshop Performance Protection Strengthening Structures Under Extreme Loading, (UEL'15), pp: 620-627.

Saadatmanesh, H. and M.R. Ehsani, 1998. Fiber composites in infrastructure. Proceedings of 2nd International Conference on Composites in Infrastructure, Jan. 5-7, Tucson, Arizona, USA. 
Seyedeh Zahra Hosseini Ghaziyani et al. / American Journal of Engineering and Applied Sciences 2018, 11 (2): 979.985 DOI: 10.3844/ajeassp.2018.979.985

ASTM C1017. "Standard Specification for Chemical Admixtures for Use in Producing Flowing Concrete, ." ASTM C1017 / C1017M - 13e1. Print.

Fast, Accurate, Small-Scale 3d Scene Capture Using a Low-Cost Depth Sensor. 2017 IEEE Winter Conference on Applications of Computer Vision (WACV). 2017. IEEE. Print.

Zhu, HX, NJ Mills, and JF Knott. "Analysis of the High Strain Compression of Open-Cell Foams." Journal of the Mechanics and Physics of Solids 45.11-12 (1997): 1875904. Print. 